\title{
Message of Biblical Apocalyptic Literature and its Relevance for Contemporary Christianity in Ghana
}

\author{
Emmanuel Foster Asamoah (D), Joseph Williams Acheampong (D), Emmanuel Kojo Ennin Antwi (D) 1 \\ ${ }^{1}$ Department of Religious Studies, Kwame Nkrumah University of Science and Technology, Kumasi, Ghana.
}

\begin{abstract}
Undoubtedly, apocalyptic literature is among the difficult literature to understand and to interpret due to its literary genre and mode of communication which is often in the form of visions. Though weird symbols and images shrouded in secrets and coded language are the content of these visions, the literature [those in the Judeo-Christian Scriptures] has been both an inspiration and a mystery to Christians in particular and Ghanaian Christians in general. Apart from serving as a motivational tool for Christians to know that true authority and power belongs to God, and among others, the literature also offers hope to Ghanaian Christians of the impending judgment at the end of this age. Though the literature has not been rightly handled by some Ghanaian pastors and Christians, the unending effect has made people hope in the Lord. This paper, therefore, contributes to the general knowledge of apocalyptic literature and accentuates how its message in the Judeo-Christian scriptures have greatly influenced the beliefs, lifestyle, and thought pattern of Ghanaians in general, and contemporary Christianity in Ghana, in particular; making them live in consonance with the message of the biblical apocalyptic literature which encourage them to develop a certain kind of belief, thought pattern, and lifestyles different from an ordinary individual, and not otherwise.
\end{abstract}

Keywords: Apocalyptic literature, apocalypse, apocalypticism, apocalyptic eschatology, Ghanaian Christianity

(C) 2020 The Author(s). Published and Maintained by Noyam Publishers.

This is an open access article under the CCBY license (http://creativecommons.org/licenses/by/4.0/).

\section{INTRODUCTION}

According to Käsemann, apocalyptic literature is "the mother of all Christian theology." ${ }^{1}$ However, this literature has suffered over the years. ${ }^{2}$ Theologians in times past recognised the literature "as an anomaly, a perversion, and was not thought to represent mainstream Jewish or Christian thought." While some paid little attention to the subject, others ignored it because of the belief that apocalyptic thought has had minimal influence on Judaism and Christianity. ${ }^{4}$ In this regard, Reddish believes that the subject has been rediscovered in recent years with scholars affirming its influence on Judaism and Christianity. ${ }^{5}$ Carter, one of such scholars, affirms that the past 40 years have witnessed the most study of apocalyptic literature more than has taken place in the last three hundred years. ${ }^{6}$ Theology has influenced modern society and contemporary Christianity. In the Judeo-Christian Scriptures, two main books-the book of Daniel and Revelation - are the most recognised apocalyptic literature. ${ }^{7}$ However, there are passages in the Old and New Testaments

\footnotetext{
Ernst Käsemann, “The Beginning of Christian Theology,” JTC 6 (1969), 40, quoted in John J. Collins, The Apocalyptic Imagination: An Introduction to Jewish Apocalyptic Literature Third Edition (Grand Rapids, Michigan: William B. Eerdmans Publishing Company, 2016$), 1$.

Mitchell G. Reddish (ed.), Apocalyptic Literature: A Reader (Peabody, Massachusetts: Hendrickson Publishers, 1995$), 33-4$.

Reddish (ed.), Apocalyptic Literature: A Reader, 34.

Reddish (ed.), Apocalyptic Literature: A Reader, 34.

John J. Collins, The Apocalyptic Imagination: An Introduction to Jewish Apocalyptic Literature Third Edition (Grand Rapids, Michigan: William B. Eerdmans Publishing Company, 2016), 1; Reddish (ed.), Apocalyptic Literature: A Reader, 34.

6 John W. Carter, An Introduction to the Interpretation of Apocalyptic Literature (www.biblicaltheology.com/Research/carterJo8.pdf), accessed on April 20, 2018.

7 There are other writings in the Judeo-Christian Scriptures that are apocalyptic in nature. Some of them are Mark 13 with parallel writings in Matthew 24 , Luke 17:22-37, and Luke 21. Others are 1 Corinthians 15:20-28, 2 Corinthians 5:1-3, 1 Thessalonians 4:15-18, and 2 Thessalonians 2:1-12.
} 
with apocalyptic features. This paper seeks to discuss apocalyptic literature and how it has been portrayed in the JudeoChristian scriptures. It also highlights the impact of this form of literature on the beliefs, lifestyle, and thought pattern of Ghanaians in general, and contemporary Christianity in Ghana.

\section{APOCALYPTIC LITERATURE Apocalypse}

There are numerous ancient works, including the book of Daniel and Revelation that are described as apocalypse. This word comes from the Greek áđ something that has been hidden. ${ }^{8}$ Such revelation is outside the comprehension of unaided human intellect but fathomable through divine disclosure to a faithful remnant that was often thought to be living in a time of eschatological crisis. ${ }^{9}$ The disclosure of this revelation is often done by an angelic being who serves as a mediator, usually to a hero of the community's past who is well-known. ${ }^{10}$ This is clearly seen in the opening statements of the book of Revelation:

This is a revelation from Jesus Christ, which God gave... He sent an angel to present this revelation to his servant John... This is his report...the testimony of Jesus Christ. God blesses the one who reads the words of this prophecy to the church, and he blesses all who listen to its message and obey what it says, for the time is near (Revelation $1: 1-3$, NLT).

John, the supposed author of the apocalypse describes that the information contained in the book are events whose fulfillment is imminent. He goes further to tell how he received it - through an angelic being, and that the angel did not fail to disclose all the information he [the angel] saw, which concerns Jesus Christ, to him. He concludes by emphasizing the blessings that accompany those who read and listen to its message, including those who obey.

J. J. Collins defines apocalypse as:

a genre of revelatory literature with a narrative framework in which a revelation is mediated by an otherworldly being to a human recipient, disclosing a transcendent reality which is both temporal, insofar as it envisages eschatological salvation, and spatial, insofar as it involves another, supernatural world. ${ }^{11}$

In other words, it is a kind of genre of literature in a specific form of revelation or prophecy mediated by beings other than humans-say, angelic - to human recipients, revealing truth that is beyond or above the range of normal or physical human experience, largely involving symbols and imagery, and predicting disaster and destruction, which are temporal and spatial. As to why such a document was written, Yabro Collins postulates that it is

to interpret present, earthly circumstances in light of the supernatural world and of the future, and to influence both the understanding and the behaviour of the audience by means of divine authority. ${ }^{12}$

Apocalypse aims to explain on-going worldly activities from a supernatural world view as a means to let its audience know and understand that divinity is in control of events and that he [God] will bring it to an end.

\section{Apocalypticism}

"As a social ideology,"13 Taylor defines apocalypticism as "the attitudes, presuppositions, expectations, and beliefs that form the religious or cultural milieu of those belonging to movements similar to those that produce apocalypses." 14 Apocalypticism holds the belief that the world mankind lives in will come to an end, usually in a cataclysmic way as foretold in some prophecy and revelation, such as in apocalypse. It anticipates the imminent divine intervention as the only panacea to evils and vices threatening a community that identifies itself as righteous remnants who see themselves as people who have been disenfranchised by their contemporaries. ${ }^{15}$ Apocalypticism is a way of thinking that may [or may not] produce literature detailing such beliefs. ${ }^{16}$ Apocalypticism is dualistic in nature; each in tension with the other. Adherents see the world in opposing terms: either belonging to the righteous or evil. ${ }^{17}$ They see the cosmos to be caught

\footnotetext{
Emmanuel Foster Asamoah, "Interpretation Approaches For Biblical Apocalyptic Literature: An Evaluation,” E-Journal of Religious and Theological Studies 6(4), (2020): 236-42. https://doi.org/10.38159/erats.2020073.

9 Richard A. Taylor, “Interpreting Apocalyptic Literature: An Exegetical Handbook" in Handbooks for Old Testament Exegesis, Edited by David M. Howard Jr. (Grand Rapids, MI: Kregel Publication, 2016), 31.

10 Taylor, "Interpreting Apocalyptic Literature" 31.

11 Reddish (ed.), Apocalyptic Literature: A Reader, 20.

12 Adela Yarbro Collins, “Introduction," in Early Christian Apocalypticism: Genre, Social Setting, ed. Adela Yarbro Collins, Semeia, vol. 36 (Decatur, GA: Scholars Press, 1986), 6; Taylor, "Interpreting Apocalyptic Literature" 32.

Collins, The Apocalyptic Imagination, 2.

4 Taylor, "Interpreting Apocalyptic Literature," 33.

Taylor, "Interpreting Apocalyptic Literature," 34.

Taylor, "Interpreting Apocalyptic Literature," 33-4.

Reddish (ed.), Apocalyptic Literature: A Reader, 23-4.
} 
up in the tension between good and evil, uprightness and wickedness, and righteous living and sinful living - no midway to stand. Also, the struggles on earth are pictured as the manifestations of the continuous battle between God and [d] evil. $^{18}$

\section{Apocalyptic Eschatology}

Apocalyptic eschatology takes a critical look at God's activity in the future. ${ }^{19}$ Since eschatology deals with end-time events, apocalyptic eschatology involves how God's divine plan for the world will be manifested at the end of time through supernatural force..$^{20}$ It hopes in the future where the wicked will suffer and the righteous will be in the afterlife. During this time the wickedness of this world will be brought to an end and there will begin the creation of a new world. ${ }^{21}$ This set of motifs are found throughout apocalyptic literature and in other literary genres and social settings. ${ }^{22}$

Apocalyptic literature includes all writings that are accepted as such, which portray apocalypse, apocalypticism, and apocalyptic eschatology, through the use of languages that are in symbols and images, as well as other related literature that may not have been accepted as such but show common features of the same genre. ${ }^{23}$

The uniqueness of this literature is that it "tends to be rich in its angelology, vivid in its eschatological expectations, dire in its warning of cataclysmic judgment, and reassuring in its announcement of vindication for the righteous." ${ }^{24}$ Since the apocalypse was written in a time of crisis to offer hope and comfort to the readers, angels were seen to be mediators between the supernatural and the natural who often carried information to individuals who were known to be past heroes to be relayed to them. The information given by the angel in most times talked about future happenings which will be sudden and violent in nature. This was to assure the righteous [or readers] who have been faced with evil and other vices that the current pain faced by the righteous was temporal which was against the everlasting peace they were to enjoy at the end of time.

Apocalyptic literature encourages readers to protest or resist actively or passively against the demands of the ruling authority or enemy, say political, military, social, theological, or whatsoever; their allegiance is to a higher authority, who is God..$^{25}$ The literature shows who true authority and power belongs to. It encourages the audience to resist claims of world tyrannical rulers, unjust systems and flaws, inadequate world views, and the suppression of faith in God to the extent of availing themselves for martyrdom in extreme kind of protest. ${ }^{26}$ For example, in Daniel 3, the Hebrew boys resisted the decree to bow to King Nebuchadnezzar and were not worried to stay in the fire. They acknowledged that all power belongs to God and He alone rules. ${ }^{27}$ The literature also puts its readers on their toes not to accept the delusions of the present world, but look ahead for a better reward from God. For example, in Revelation 21, the author assures the audience of a better world - new heaven - they will inherit at the end of time.

All these and others are found in the books of Daniel and Revelation of the Judeo-Christian Scriptures. ${ }^{28}$ These writings have influenced [and still influence] Christianity in general with Ghanaian Christianity not exempted.

\section{CHRISTIANITY IN GHANA}

According to history, Christianity was introduced in Ghana (then Gold Coast) in the late fifteenth century by European missionaries, specifically the Portuguese Catholics, who accompanied their traders as chaplains for trade expedition. ${ }^{29}$ These chaplains came possibly with the Judeo-Christian Scriptures [or Bible] in their mother-tongue or language they could read. By the end of the twentieth century, Christianity had been able to gain ground due to the continuing influx of missionaries. This period witnessed the institution of western mission churches. ${ }^{30}$ The early part of the twentieth century

\footnotetext{
18 Reddish (ed.), Apocalyptic Literature: A Reader, 24.

Reddish (ed.), Apocalyptic Literature: A Reader, 19.

Collins, The Apocalyptic Imagination, 19-20.

Collins, The Apocalyptic Imagination, 2, 20.

Collins, The Apocalyptic Imagination, 2.

Taylor, "Interpreting Apocalyptic Literature, 34

Taylor, "Interpreting Apocalyptic Literature, 34; For other features of Apocalyptic Literature, See; Emmanuel Foster Asamoah, An Assessment of the translation of TO AАФA KAI TO $\Omega$ as Alfa ne Omega no in the Greek New Testament (Revelation 1:8) and Asante-Twi Twere Kronkron (Sacred Writings), Unpublished MPhil Thesis, (Kumasi: KNUST, 2019), 29.

25 Reddish (ed.), Apocalyptic Literature: A Reader, 25.

26 Reddish (ed.), Apocalyptic Literature: A Reader, 26.

7 Reddish (ed.), Apocalyptic Literature: A Reader, 26.

28 There are other writings in the Judeo-Christian Scriptures that are apocalyptic in nature. Some of them are Isaiah 24-27 \& 33; Joel 2:1-11; Mark 13 with parallel writings in Matthew 24, Luke 17:22-37, and Luke 21. Others are 1 Corinthians 15:20-28, 2 Corinthians 5:1-3, 1 Thessalonians 4:15-18, and 2 Thessalonians 2:1-12.

29 Hans W. Debrunner, A History of Christianity in Ghana (Accra: Waterville Publishing House, 1967), 17-8. Alfred Koduah, Christianity in Ghana Today (Accra: Alfred Koduah, 2004), 22.

30 These western churches were established: Presbyterian Church, Methodist Church, Evangelical Presbyterian Church, Roman Catholic Church, Seventh Day Adventist Church, Church of the Prince of West Africa, Salvation Army, Assemblies of God, and the Apostolic Church \& The Church of Pentecost. See; Koduah, Christianity in Ghana Today, 22, quoted in Kofi Asare Opoku, "A Brief History of Independent Church Movements in Ghana since 1862" in The Rise of Independent Churches in Ghana (Accra: Asempa Publishers, 1990), 7.
} 
also witnessed the institution of African Independent Churches or Spiritual Churches by some Ghanaian leaders because they were dissatisfied with realising the African spirit in these churches. ${ }^{31}$ This was a result of the ministry of Prophet Wade Harris which sought to contextualise the gospel message in African culture. Harris used the Bible in ministration. ${ }^{32}$ However, their actions led to syncretism - a situation where Christianity is mixed with the traditional African religious system. ${ }^{33}$ According to Koduah, this practice set the stage for the institution of classical Pentecostal churches ${ }^{34}$ to provide the lost ingredients in Ghanaian Christianity-the social fellowship, emotional experiences, emotional security against evil forces, and healing. ${ }^{35} \mathrm{He}$ postulates that classical Pentecostal churches met the aspirations of the people by providing the lost ingredients. ${ }^{36}$ They also succeeded in propagating a more balanced salvation message with an emphasis on the end of the believer and the evil one, which seems to meet the desires and aspirations of the African. ${ }^{37}$ Their message was the "Four-square Gospel" 38 with emphasis on apocalyptic warnings. Another factor that paved way for the institution of the classical Pentecostal churches was the worldview of Ghanaian people and culture which is always seeking to punish evildoers. The gospel message preached in its entirety touched on the destiny of the righteous and the wicked, in the here-and-now, and at the end of times. Since God is supreme than all gods and spiritual forces, Ghanaians found it convenient to shelter under the canopy of God who punishes the wicked and award his own. The late twentieth century witnessed the emergence of Neo-Pentecostals or Charismatic churches ${ }^{39}$ from classical Pentecostals with slight differences in an ecclesiastical and theological framework..$^{40}$ Other churches that sprung up later are those known as the Third Wave movement which operates like the Pentecostal churches. ${ }^{41}$

Currently, there are hundreds of denominations in Ghana which come under four main Christian bodiesGhana Catholic Bishops Conference, the Christian Council of Ghana, the Ghana Pentecostal and Charismatic Council, and the National Association of Charismatic and Christian Churches. According to the 2010 national population census report, the Christian population was 71.2 percent, out of which [Christians in Ghana] 39.75 percent were Pentecostals, 25.84 percent were Protestants, 18.40 percent were Roman Catholics, and 16.01 percent were Other Christians. ${ }^{42}$ The current Ghanaian population is predominantly Christians who rely heavily on the content of the Judeo-Christian Scriptures which has apocalyptic writings. This has had such a pervasive influence on society and Ghanaian Christians.

\section{RELEVANCE OF APOCALYPTIC LITERATURE FOR CONTEMPORARY CHRISTIANITY IN GHANA}

Apocalyptic literature has influenced most Ghanaian songs-both sacred and secular, for 71.2 percent of Ghanaians are Christians. ${ }^{43}$ These songs seek to offer comfort for the present and hope for the future. Pentecostal songs such as Asafo Yehowa, sore $e^{44}$ (Arise, Oh! Lord), and O Israel Yakob Nyame ${ }^{45}$ (O God of Israel and Jacob) seek to comfort Christians of their present challenges and offer them hope of the intervention of God in the activities of humanity in the distant future. Some of the songs on the Ghanaian airwaves especially the secular ones carry lyrics of comfort, justice in the present acts of humanity, and eschatology. Kofi Kinata's song Things Fall Apart is a clear example of such a song. Though known as "a secular musician," the Artiste reveals the rotten behaviour some pastors have been engaging in, which to him has made "things fall apart". Rhetorically, he advises church leaders and Christians to desist from such practices to escape from God's punishment at the judgment and rather get the reward He has promised.

Another area where Ghanaian Christians have been influenced by apocalyptic writings is in their prayer. Idowu in his description of how prayerful Africans pray writes: "Prayers are offered, not only at worship but also at any time

\footnotetext{
31 Some of the African Independent Churches formed were Faith Healing Church, the Twelve Apostles Church, the West African Water Healing Society, Kajirfeh Divine, African Faith Tabernacle Church, Mosama Disco Christo Church, Apostles Revelation Society, and Savior Church. See; Koduah, Christianity in Ghana Today, 30-4.

32 He was an itinerant preacher from Liberia who wore a white gown and a turban, carried a bamboo cross, a Judeo-Christian Scriptures [or Bible], and a calabash for baptism. See; Gordon M. Haliburton, The Prophet Harris (London: Oxford University Press, 1973), 49; Koduah, Christianity in Ghana Today,31. Koduah, Christianity in Ghana Today, 37.

34 Some of the Classical Pentecostal churches formed were the Assemblies of God Church in 1931, The Apostolic Church in 1935, The Christ Apostolic Church in 1939, and The Church of Pentecost in 1953. Other notable churches emerged from these churches. See; Koduah, Christianity in Ghana Today, $39-56$.

35 Debrunner, A History of Christianity in Ghana, 50, 320.

36 Koduah, Christianity in Ghana Today, 49-56.

37 Koduah, Christianity in Ghana Today, 38.

38 This Gospel centres on Jesus as the Saviour, Jesus the Healer, Jesus the Baptiser in the Holy Spirit and Jesus the soon coming King.

39 Some churches established were Action Faith Chapel Ministry and International Central Gospel Church. Read; Koduah, Christianity in Ghana Today, 94-114.

40 Stanley M. Burgess and Gary B. McGee (eds.), Dictionary of Pentecostals and Charismatic Movements (Grand Rapids: Zondervan Publishing House, 1988), 155-6.

41 Koduah, Christianity in Ghana Today, 101

42 Original rates out of the $71.2 \%$ are; Pentecostals $28.3 \%$, Protestants 18.4\%, Roman Catholics 13.1\%, Other Churches $11.4 \%$. See; Ghana Statistical Service, 2010 Population \& Housing Census: Analytical Report, Accessed on May 23, 2020, from https://statsghana.gov.gh/gssmain/fileUpload/pressrelease/2010 PHC National_Analytical Report.pdf.

43 Ghana Statistical Service, 2010 Population \& Housing Census: Analytical Report, Accessed on May 23, 2020, from https://statsghana.gov.gh/gssmain/fileUpload/pressrelease/2010_PHC_National_Analytical_Report.pdf.

44 The Church of Pentecost General Headquarters, Pentecost Songs Book: English and Twi (Accra: Pentecost Press Ltd., 2016$), 207$.

45 The Church of Pentecost General Headquarters, Pentecost Songs Book: English and Twi, 316.
} 
and in any place." ${ }^{46}$ Hence, Ghanaian Christians love to pray always. This is clearly seen in most of their television and radio presentations. The Multi TV, a free-to-air terrestrial decoder has more Christian TV stations that show all forms of prayers which are conducted all-night, half night, all day, etc. and organised by churches. Listening to the prayer topics that are raised at these prayer sessions, most of them are focused on calls for the intervention of God on the wicked and for His (God) children to be freed from current economic, social, and spiritual hardships. Among the topics often prayed for are that; "God deal with my enemies" and "The end of the wicked." Prayer sessions on such topics are attended in numbers and participants go to pray for deliverance.

The third relevance of apocalyptic literature is the help it offers in communication. Communication is said to be the lifeline of every organisation without which an organisation cannot operate. ${ }^{47}$ For one to be able to get the understanding of a message, it ought to be communicated in the way and manner which they understand. This calls for choosing an appropriate language style. Since apocalypse presents the symbols and myths of what was Scripture in a new visionary form, the genre has provided the right language style that meets contemporary Christian beliefs. ${ }^{48}$ It helps Christians to get a clearer understanding of the symbolic language of the literature. Though not all the symbols are literal and easily understood as is the case of the book of Revelation, some symbols have helped Ghanaian Christians to understand some biblical concepts. ${ }^{49}$

The literature offers no reason for resorting to a life based solely on fantasy; hence, it serves as a motivational tool..$^{50}$ Most of the visions in apocalyptic literature often have an end-time inclination which often serves as catalysts, motivating the people of God to work to make those visions become a reality. These visions often centre on freedom, peace, justice, and reconciliation. The Church of Pentecost, and other Pentecostal Churches like the Christ Apostolic Church International, for instance, have in their tenets the second coming of Christ and life in the next world which is pictured in the apocalyptic literature as events to happen in the distant future. ${ }^{51}$ They believe that the death of a person does not end his/her life, but continues in the next world; either to eternal joy or damnation. This is clearly identified in the book of Revelation which describes events beyond this world. For example, in Revelation 20:2-3, the writer talks about what will happen to the old dragon who deceived Adam and continues to deceive mankind. That he would be cast into the bottomless pit, and shut him up, and a seal set on him, so that he should deceive the nations no more till the thousand years were finished. The literature also puts its readers on their toes not to accept the delusions of the present world, but look ahead for a better reward from God in the land of peace and justice. For example, Apostle Eric Nyamekye, the Chairman of the Church of Pentecost, is fond of encouraging Christians to eschew evil practices at work and wherever they find themselves for they are not of this world. He opines that Christianity is an exclusive religion; hence its adherents must not live as worldly people..$^{52}$ These among others serve as motivating factors for Christian moral uprightness, for they know that surely in the end, they will enjoy a better home where evil will be no more.

As crisis and protest literature, apocalyptic books often give hope to readers and for them to know that true authority and power belongs to God. This encourages them to resist claims of world tyrannical rulers, unjust systems, inadequate world views, and the suppression of faith in God to the extent of availing themselves for martyrdom in extreme kind of protest. ${ }^{53}$ An example is when the majority of Ghanaians in their numbers took to the streets and thronged various media houses to register their displeasure and also protest against a comment made by the President of the Republic, Nana Addo Danquah Akufo-Addo on same-sex marriage which sought to destroy their theology. ${ }^{54} \mathrm{His}$ comment did not suggest to approve of their activities, for he later responded that "Government will not change laws on same-sex marriage." ${ }^{55}$ However, Ghanaians vehemently protested so that the practice will not be accepted even when same-sex activists push the boundaries. Ghanaians believe that such activities are evil, and they would not allow them to

\footnotetext{
46 E. Bolaji Idowu, Oludumare: God in Yuroba Belief, (London: Longman, 1962), 117.

47 Deepa Sethi and Manisha Seth, "Interpersonal Communication: Lifeblood of an Organisation," The IUP Journal of Soft Skills, Vol. III, 3 \& 4 (2009):32-40.

48 The New Interpreter's Bible, General Articles \& Introduction, Commentary, Reflections for each Book of the Bible including The Apocryphal Deuterocanonical Books in Twelve Volumes, Volume XII (Nashville: Abingdon Press, 1998), 506-7.

49 Henry Barclay Swete, The Apocalypse of St. John: The Greek Text with Introduction Notes And Indices, (Grand Rapids, Michigan: Wm. B. Eerdmans Publishing Company, 1968), cxxxi-iv.

50 The New Interpreter's Bible, General Articles \& Introduction, Commentary, Reflections for each Book of the Bible including The Apocryphal Deuterocanonical Books in Twelve Volumes, Volume XII (Nashville: Abingdon Press, 1998), 507.

51 The Church of Pentecost General Headquarters, Ministerial Handbook, (Accra: Pentecost Press Ltd., 2018), 14; Christ Apostolic Church Int., Tenets, accessed on June 27, 2020 from https://cac-int.org/our-tenets/.

52 Christianity Is An Exclusive Religion, directed by Kwasi Annor (Accra: PentMedia, 2019), DVD, $94 \mathrm{~min}$.

53 Reddish (ed.), Apocalyptic Literature: A Reader, 26.

54 In an interview with Gulf news, the President said, "I don't believe that in Ghana so far a sufficiently strong coalition has emerged which is having that impact of public opinion that will say, change it; let's then have a new paradigm in Ghana." See "Homosexuality not on Ghana's agenda-President Akufo-Addo (Africa News, 2017) (Accessed on June 25, 2020, from https://www.africanews.com/2017/11/26/homosexuality-not-on-ghana-s-agenda-president-akufoaddo/). Speaker of Parliament, Rt. Hon. Prof. Mike Aaron Ocquaye was part of those that spoke against accepting same-sex marriage in Ghana. See; Raymond A. Atuguba, "Homosexuality in Ghana: Morality, Law, Human Rights," Journal of Politics and Law, 12(4) (2019): 113-126.

55 I have no plan to bring same sex-marriage in Ghana-Prez Akufo-Addo, produced by Jubilee House Communications Directorate, 9/08/2018 (2018; https://www.youtube.com/watch? $\mathrm{v}=\mathrm{do} 4$ boquC7H0).
} 
thrive in the nation, for God abhors such acts. ${ }^{56}$

The next relevance is that the literature has served as a reminder to all Christians. They have come to understand that the world as it is was created perfectly by God, without imperfections. But along the line, evil activities and immoral practices have brought the world this far. Apocalyptic literature brings out the picture clearer when, for example, Babylon the Great is portrayed primarily in its commercial and political dimensions which represents the ungodly world system. The author of the Book of Revelation describes their sinful activities like that which are piled up to heaven as the enormous sin of Sodom which 'had grown very great' (Gen. 18:20). He reveals that these activities would be brought low in one day by the actions of God. In those moments, kings of the earth will lament over the burning of their former mistresses. This seems to be the preaching and teaching of almost all the churches in Ghana, especially the Protestants, Pentecostals, and Charismatics. For example, the Church of Pentecost has in its tenets the depravity of human nature which teaches the sinfulness of man and the need to seek a saviour. ${ }^{57}$ There is also the need to live upright so that Christians will inherit a new world that will come at the end of time after this present groaning world is destroyed.

Furthermore, like in the days of John when he wrote to encourage Christians who were facing challenges such as torture and martyrdom under the emperor's rule, so also contemporary Christians are being encouraged to confront the "beasts" of modern society. The "beasts" may assume to be political, economic, social, or religious. Any individual or institution that dehumanizes and oppresses the people of the world has taken on the role of the apocalyptic beasts; hence they need to be endured. This is stated in the national anthem of Ghana, and Christians who are in the majority are always ready to resist any move that may seem to impede their freedom, rights, and relationship with God, for they do not align with the teachings of Christ. ${ }^{58}$ This paints the picture of them being controversial, costly to themselves and to public esteem because they fail to conform to the expectations of the world. ${ }^{59}$ An example can be cited when the founder and Presiding Bishop of Victory Bible Church in Ghana, in an interview on Starr FM in Accra, sought to fight for his freedom of worship which in his opinion had been taken away by the President as a result of the imposition of restrictions on social gatherings as part of the measures to stop the spread of COVID-19 pandemic. ${ }^{60}$ This subtle or passive agitation rings the bell that any attempt to prevent Christians from worship without any reason will not be accepted lightly. However, others overlooked the President's directive on social gatherings because they perceived that it was a threat to and suppression of Christianity. ${ }^{61}$

The next relevance is the ability of apocalyptical literature to offer hope in a seemingly hopeless environment. Apocalyptic writings continue to offer hope also to Christians who feel overwhelmed by the world. The problems confronting the modern world of which Christians are part are certainly enormous i.e. the effects of overpopulation, environmental pollution and deterioration, the threat of nuclear annihilation, global conflicts, crime, poverty, various pandemics, and hunger. The apocalyptic writers invite their modern readers to look beyond the problems to the God who is still sovereign over the universe. It also offers an alternative optimism and happiness for the future, the "involuntary memory of a redeemed humanity which contrasts with convention and false tradition." 62 It puts them in anticipation of a better future which is yet to come. It is on this that apocalyptic literature challenges contemporary Christians to look beyond the current suffering and pain and look to God who is sovereign.

As a type of literature that gives a prediction of the final judgment, ${ }^{63}$ apocalyptic literature warns followers of Christ [Ghanaian Christians] of the impending judgment at the end of this age. It describes the last judgment as the great day of reckoning where everything-individuals, nations, and demons will be brought to be judged according to their works. ${ }^{64}$ The sinfulness of nature due to the works of the devil which led to the fall of humankind will be rectified, evil will be chastised, and righteousness will be rewarded. ${ }^{65}$ Apocalyptic literature holds that evil and injustice will not prevail forever; they will give way for God's final judgment. ${ }^{66}$ But living as a distinct minority ${ }^{67}$ Christians can become dispirited

\footnotetext{
56 One of such is the current Speaker of Ghana's Parliament who has categorically said that homosexuality will not thrive in Ghanaian society under his watch as Speaker. He went on to caution that he would rather resign than preside over any debate on the floor of Parliament concerning same-sex matters. See; Atuguba, "Homosexuality in Ghana: Morality, Law, Human Rights," 113-126.

57 The Church of Pentecost General Headquarters, Ministerial Handbook, (Accra: Pentecost Press Ltd., 2018$), 12$.

58 The New Interpreter's Bible, General Articles \& Introduction, Commentary, Reflections for each Book of the Bible including The Apocryphal Deuterocanonical Books in Twelve Volumes, Volume XII (Nashville: Abingdon Press, 1998), 507.

59 The New Interpreter's Bible, General Articles \& Introduction, Commentary, Reflections for each Book of the Bible including The Apocryphal/ Deuterocanonical Books in Twelve Volumes, 507.

60 This was in a live interview with Bola Ray on Starr Chat programme at Starr FM, Accra on May 22, 2020.

${ }_{61}$ Pastor Sampson Agakpe (Founder of Church of Pure Christ in the South Dayi District in the Volta Region), Maxwell Dzogoedzikpe (Assistant pastor), and Samuel Agakpe (Secretary). They were later arranged for Kpando Circuit Court in the same district.

62 Christopher Rowland and Mark Corner, Liberating Exegesis: The Challenge of Liberation Theology to Biblical Studies, (Louisville, Kentucky: Westminster/ John Knox Press, 1989), 148; The New Interpreter's Bible, General Articles \& Introduction, Commentary, Reflections for each Book of the Bible including The Apocryphal/Deuterocanonical Books in Twelve Volumes, 509.

${ }_{63}$ Reddish (ed.), Apocalyptic Literature: A Reader, 22.

${ }_{64}$ Reddish (ed.), Apocalyptic Literature: A Reader, 22.

65 Reddish (ed.), Apocalyptic Literature: A Reader, 22.

${ }^{66}$ Reddish (ed.), Apocalyptic Literature: A Reader, 22.

67 Leon Morris, Apocalyptic (Grand Rapids, Michigan: William B. Eerdmans Publishing Company, 1972), 34-61.
} 
and feel crushed.

It must however be observed that the uniqueness of the literature which is rich in the activities of angelic beings seen to be mediators between the supernatural and the natural often carrying information to individuals have had various effects on some religious leaders. Some religious leaders have since assumed the role of "angels" and claim to mediate between the supernatural and natural as a means of revealing the truth that is beyond or above the range of normal or physical human experience and to offer directions and support to believers. This affirms Reddish assertion that the literature has suffered mishandling and misinterpretation from some contemporary preachers who use it for supporting their flawed standpoints. ${ }^{68}$ One of such is the founder and General Overseer of the International God's Way Church, Bishop Daniel Obinim who is known in Ghanaian Christianity as "Angel Obinim." ${ }^{69}$ While some Christians do not admit their angelic ministration, others hold them in high esteem and have testified to have had encounters with them. For example, to some, Angel Obinim has appeared in their dream to give them lotto numbers which they staked and won and this has eased their sufferings and hardships, and others have also testified of other assistance they have received. ${ }^{70}$ Though the literature has not been rightly handled by some Ghanaian pastors and Christians, the unending effect has made people hope in the Lord.

\section{CONCLUSION}

Apocalyptic literature has had a great influence on Christianity, no wonder it has been rediscovered in later years. The relevance of this literature cannot go unnoticed in contemporary Ghanaian Christianity. As it influenced Judaism and early Christianity, so is apocalyptic literature influencing modern Christians with Ghanaian Christians being no exception. This finds expression in the beliefs, thought pattern, and lifestyle which aligns with the message of the biblical apocalyptic literature. The style of songs-sacred or otherwise-of Ghanaians Christians do not only offer comfort for the present and hope for the future, rather they call the attention of individuals to God's judgment on the wicked. Furthermore, in their prayers, they call on God to intervene directly to free them from current economic, social, and spiritual hardships. In addition, Ghanaian Christians have opposed tyrannical rulers, unjust systems and the suppression of their faith in God among other things based on apocalyptic literature. The consciousness of Ghanaian Christians having "another world in view", coupled with the hope of God's ultimate intervention in their current predicaments thus becomes a remarkable motivating factor for their endurance and adherence to Christian values.

\section{ABOUT AUTHORS}

Emmanuel Foster Asamoah, MPhil, Research Associate, Department of Religious Studies, Kwame Nkrumah University of Science and Technology, Kumasi., Ghana. District Pastor, The Church of Pentecost, Antoakrom, Kumasi.

Joseph Williams Acheampong, Lecturer, Department of Religious Studies, Kwame Nkrumah University of Science and Technology, Kumasi.

Emmanuel Kojo Ennin Antwi, Senior Lecturer, Department of Religious Studies, Kwame Nkrumah University of Science and Technology, Kumasi.

\section{BIBLIOGRAPHY}

Africa News, Homosexuality not on Ghana's agenda-President Akufo-Addo. Accessed on July 25, 2020 from https://www.africanews.com/2017/11/26/homosexuality-not-on-ghana-s-agenda-president-akufo-addo/

Asamoah, Emmanuel Foster, An Assessment of the translation of TO AАФA KAI TO $\Omega$ as Alfa ne Omega no in the Greek New Testament (Revelation 1:8) and Asante-Twi Twere Kronkron (Sacred Writings), Unpublished MPhil Thesis. Kumasi: Kwame Nkrumah University of Science and Technology, 2019.

Asamoah, Emmanuel Foster "Interpretation Approaches For Biblical Apocalyptic Literature: An Evaluation," E-Journal of Religious and Theological Studies, 6(4), (2020): 236-42. https://doi.org/10.38159/erats.2020073

Asante, Kwasi, dir. Christianity Is An Exclusive Religion. 2019. Accra: PentMedia, 2019. DVD, 94 min.

Atuguba, Raymond A. "Homosexuality in Ghana: Morality, Law, Human Rights," Journal of Politics and Law, 12(4) (2019): 113-126.

\footnotetext{
68 Reddish (ed.), Apocalyptic Literature: A Reader, 34.

69 At a point, Angel Obinim sees himself as a supernatural being to have visited heaven. And at other times, he is a natural person. Some Christians have also confirmed. See; Do not judge / I saw Bishop Obinim in Heaven - Prophet Nigel Gaisie, directed by n/d (2018; https://www.youtube.com/watch?v=IzGIoK 3Amw).

70 Musician Nukre Talks About Angel Obinim \& His Dreams, directed by Sammy Flex (2019; https://www.youtube.com/watch?v=yynNqskCPmU).
} 
Burgess, Stanley M. and Gary B. McGee (eds.), Dictionary of Pentecostals and Charismatic Movements. Grand Rapids: Zondervan Publishing House, 1988.

Carter, John W. An Introduction to the Interpretation of Apocalyptic Literature. Accessed on April 20, 2018 from https://www.biblicaltheology.com/Research/CarterJ08.pdf

Christ Apostolic Church Int., Tenets. Accessed on June 27, 2020 from https://cac-int.org/our-tenets/

Collins, Adela Yarbro, "Introduction," in Early Christian Apocalypticism: Genre, Social Setting, ed. Adela Yarbro Collins, Semeia, vol. 36. Decatur, GA: Scholars Press, 1986.

Collins, John J. The Apocalyptic Imagination: An Introduction to Jewish Apocalyptic Literature Third Edition. Grand Rapids, Michigan: William B. Eerdmans Publishing Company, 2016.

Debrunner, Hans W. A History of Christianity in Ghana. Accra: Waterville Publishing House, 1967.

Do not judge / I saw Bishop Obinim in Heaven - Prophet Nigel Gaisie. 2018. https://www.youtube.com/watch?v=IzGIoK_3Amw

Flex, Sammy, dir. Musician Nukre Talks About Angel Obinim \& His Dreams. 2019. https://www.youtube.com/watch?v=yynNqskCPmU

Ghana Statistical Service, 2010 Population \& Housing Census: Analytical Report. Accessed on May 23, 2020, from https://statsghana.gov.gh/gssmain/fileUpload/pressrelease/2010_PHC_National_Analytical_Report.pdf

Haliburton, Gordon M. The Prophet Harris. London: Oxford University Press, 1973.

Jubilee House Communications Directorate, prod. I have no plan to bring same sex-marriage in Ghana - President AkufoAddo. 2018. https://www.youtube.com/watch?v=do4boquC7H0

Idowu, E. Bolaji, Oludumare: God in Yuroba Belief. London: Longman, 1962.

Käsemann, Ernst, “The Beginning of Christian Theology," JTC 6 (1969), 40, J. Collins, The Apocalyptic Imagination: An Introduction to Jewish Apocalyptic Literature Third Edition. Grand Rapids, Michigan: William B. Eerdmans Publishing Company, 2016.

Koduah, Alfred, Christianity in Ghana Today. Accra: Alfred Koduah, 2004.

Opoku, Kofi Asare, "A Brief History of Independent Church Movements in Ghana since 1862" in The Rise of Independent Churches in Ghana. Accra: Asempa Publishers, 1990.

Reddish, Mitchell G. (ed.), Apocalyptic Literature: A Reader. Peabody, Massachusetts: Hendrickson Publishers, 1995.

Rowland, Christopher and Mark Corner, Liberating Exegesis: The Challenge of Liberation Theology to Biblical Studies. Louisville, Kentucky: Westminster/John Knox Press, 1989.

Sethi, Deepa and Manisha Seth, "Interpersonal Communication: Lifeblood of an Organisation," The IUP Journal of Soft Skills, Vol. III, 3 \& 4 (2009):32-40.

Swete, Henry Barclay, The Apocalypse of St. John: The Greek Text with Introduction Notes And Indices. Grand Rapids, Michigan: Wm. B. Eerdmans Publishing Company, 1968.

Taylor, Richard A. "Interpreting Apocalyptic Literature: An Exegetical Handbook" in Handbooks for Old Testament Exegesis, Edited by David M. Howard Jr. Grand Rapids, MI: Kregel Publication, 2016.

The Church of Pentecost General Headquarters, Ministerial Handbook. Accra: Pentecost Press Ltd., 2018.

The New Interpreter's Bible, General Articles \& Introduction, Commentary, Reflections for each Book of the Bible including The Apocryphal/Deuterocanonical Books in Twelve Volumes, Volume XII. Nashville: Abingdon Press, 1998. 